\title{
Improving Dermatological Signs and Symptoms with Polydatin-based Dermo-Cosmetic Products
}

\section{Nicola Venturo ${ }^{1}$ and Giovanni Suffritti ${ }^{2 *}$}

${ }^{1}$ Department of Dermatology and Venereology, the University of the Republic of San Marino, Rome, Italy

${ }^{2}$ Department of Research \& Development, Ghimas, Casalecchio di Reno, Bologna, Italy

*Corresponding author: Giovanni Suffritti, Department of Research \& Development, Ghimas, Via Domenico Cimarosa, 85-40033 Casalecchio di Reno, Bologna, Italy, Tel: +39 051 575353; E-mail: giovanni.suffritti@ghimas.it

Received date: June 06, 2017; Accepted date: August 31, 2017; Published date: September 03, 2017

Copyright: ( 2017 Venturo N, et al. This is an open-access article distributed under the terms of the Creative Commons Attribution License, which permits unrestricted use, distribution, and reproduction in any medium, provided the original author and source are credited.

\begin{abstract}
Objective: The aim of study is to evaluate the effectiveness of polydatin in improving dermatological signs and symptoms.

Methods: Included 110 adult patients, also with lesions on the trunk and limbs: 64 with atopic dermatitis, 25 with seborrheic dermatitis of the face and 21 with eczema of face or eyelids. All patients applied in the morning and in the evening the hypoallergenic cream with polydatin $1.5 \%$ or body formulation with polydatin $0.8 \%$ in relation to the area of the lesion to be treated, also using the cleaning formulation for normal daily cleaning.
\end{abstract}

Results: The patients showed a reduction of variable degree of lesions and subjective dermatological symptoms, such as itching, erythema, xerosis, lichenification of the skin and eczematous lesions.

Conclusion: The use of topical cream and cleanser restores the function of the skin barrier, counteracts the action of irritants or allergens, reduces the local inflammatory response, and eliminates the itching and scratching.

Keywords: Polydatin; Dermopathy; Itching; Erythema; Xerosis; Lichenification; Eczema; Topical therapy

\section{Introduction}

Atopic dermatitis is not only paediatric dermatoses. Although usually begin at an early age, often before two years, this disease does not disappear before adolescence and adulthood. It is estimated that $10 \%$ of patients continue to suffer the manifestations of eczema in adulthood. In a number of cases, this eczema remains worrying, and can cause difficult problems in patient life [1,2].

The adult atopic dermatitis is often severe dermatoses, with chronic eczema, red, thick and lichenified plaques, sometimes with isolated papules of prurigo. On this background of chronic eczema acute exacerbations occur, which may be vesicular or weeping. The itching is always intense, hindering daily life, morale, sleep and normal activities. The locations are different from those of children's atopic dermatitis. The hands, the face, especially the eyelids, are the hardest hit points along with large folds, and possibly other parts of the body. The inflammatory exacerbations can affect the whole skin. In this case we speak of erythroderma, a serious disease that can be complicated by infections and metabolic disorders, requiring hospitalization.

In addition, in the atopic dermatitis, there may be an alteration of saprophytic microbial flora (microbiota) that colonizes the skin. Exudative eczema causes a breakdown of normal balance between harmful (commensal) bacteria and pathogenic bacteria. Staphylococci may be responsible for infections and are often associated with inflammatory exacerbations, even though they do not appear clinically over-infected in an obvious manner. This is why commonly antibiotic surveillance is required.

The herpes virus infection is often very serious in atopic patients and presents with pustules that can leave scars similar to those of chickenpox or smallpox.

Other pathologies, in addition to adult atopic dermatitis, clinically present a common form of eczema, such as severe seborrheic dermatitis and allergic contact dermatitis.

In the case of allergic contact dermatitis after skin contact with substances (allergens) that can stimulate an immunological response, there is an inflammatory reaction clinically characterized by the appearance of erythema and vesicles.

In the seborrheic dermatitis of the face, on the other hand, there are on an erythematous basis, yellowish and often pruriginous scales, usually present to the hair attachment, nose and ear pads.

At the beginning of these dermatitis, factors such as genetic predisposition and negative emotional states (depression, anxiety and stress), as well as anomalies of the natural defense system and unfavourable external environmental conditions (presence of high humidity, atmospheric pollution and smog) can act. Hormonal imbalances or exposure to aggressive and irritating detergents also play an important role.

Usually the basic treatment of atopic dermatitis involves: 


\section{Hygiene measures}

Day-to-day emollient treatment is of great importance, being the true therapeutic key to counteract the pathogenesis of dermatosis (with simple and rational composition moisturizers, effective and pleasing to use)

A topical anti-inflammatory treatment (dermo-corticoids and sometimes tracrolimus) to counteract exacerbations and possibly prevent them.

Understanding the importance of this local treatment and the need for adherence to it is not easy for the patient and its prescription must be accompanied by information-education measures, oral and written by the physician.

This "standard" treatment is very effective, if well accepted, well understood and well realized. Therefore, before talking about resistance to the treatment of atopic dermatitis, and before thinking about changing the prescription, it must be sure that the treatment has been carried out correctly.

The oral corticosteroid and immunosuppressant therapy have a good effect on atopic dermatitis. They are still drugs that, when used in the long term, will incur the side effects that may be more serious than the disease itself.

It is generally accepted that oral corticosteroids are really contraindicated in atopic dermatitis, because the side effects and steroid-dependence are inevitable [3]. Furthermore, today we can have some good immediate results with a strong local corticosteroid therapy, time-limited.

According to of what has emerged from studies of the researchers on promising anti-inflammatory capacity of polydatin (), we tested its efficacy in treatment with dermo-cosmetic formulations in patients with dermatitis.

\section{Polydatin}

The stilbenes are a vegetable substance of the family of fitoalexine, capable of interacting with biological structures by activating repair processes and defense mechanisms.

Polydatin is the glucoside of resveratrol, which is known for its powerful action against free radicals [4].

Compared to resveratrol, polydatin has many advantages:

Increased resistance to enzymatic oxidation

It penetrates the cell via an active carrier mechanism using glucose carriers

Due to its water solubility, polydatin is totally absorbed in the intestine

Consequently the bioavailability of polydatin is $4-5$ times greater than that of resveratrol, with a total absence of side effects in the intestine (diarrhoea) caused by high amounts of resveratrol [5-8].

A proportion of polydatin, once inside the cell is transformed into resveratrol by the presence of glycosidase, with diffusion in various organs and apparatuses [9].

Polydatin neutralizing free radicals inhibits lipid peroxidation, which leads to destruction of membrane lipids and determines the formation of modified LDL (fundamental in the genesis of the atheroma), reducing the atherogenic index, thus exerting cardioprotective action [4] and improving the metabolic syndrome [10]. Polydatin reduces also the inflammatory response through modulation of the nitric acid and production of cytokines, which have regulatory and pro-inflammatory properties [11-14].

Polydatin is also capable of increasing beta defensin, which normalizes the inflammatory process and boosts the immune system of the skin [10,15-20].

Although the authors provide evidence of systemic and in vitro effects of resveratrol and resveratrol glycoside (polydatin) and there is limited evidence of the in vivo advantage of the latter on the skin, the evidence in our clinical experience of good results (reduction of itching, redness, xerosis, lichenification, and eczematous skin lesions) after the topical application of polydatin-based dermocosmetics, has prompted us to document its action in a wider number of dermatological patients.

In this open, uncontrolled clinical study performed in a specialized dermatological center in Bologna (Italy) we have evaluated the effectiveness of polydatin in patients affected by dermopathy. All subjects provided written informed consent to treatment, in accordance with the ethical guidelines of the Helsinki declaration and its subsequent amendments.

\section{Materials and Methods}

We checked 110 patients affected by dermopathy: 64 with atopic dermatitis localized to the arms ( 25 cases), to the face ( 10 cases), to a retro-ear level (8 cases), to the neck (9 cases), to the wrists ( 7 cases) and to the popliteal region ( 5 cases), 25 with seborrheic dermatitis of the face and 21 with eczema of face or eyelids (Figure 1).
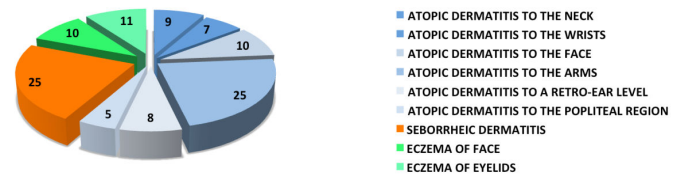

Figure 1: Diagnosis of dermatitis

In the first visit it was assessed, together with a detailed medical history, the subjective and objective clinical situation of dermatitis, particularly itching, redness, xerosis, lichenification, and eczematous skin lesions. At this stage we excluded from the study patients with allergic contact dermatitis.

We evaluated the symptoms with a semi-quantitative scale (0-no, 1symptom of middle grade; 2 -a symptom of high level) and were made an evaluation of the effectiveness of treatment by both the patient and doctor (0-totally ineffective, up to 10-excellent efficacy).

All patients applied in the morning and in the evening the hypoallergenic cream with polydatin $1.5 \%$ or body formulation with polydatin $0.8 \%$ in relation to the area of the lesion to be treated, also using the polydatin-based cleanser for normal daily skin cleaning.

Throughout the duration of the study, all patients have guaranteed not to use on areas with dermatitis other dermocosmetics, other types of soap or cleanser, and other supplements taken, any forms of corticosteroid/tacrolimus creams other than the test products. 
Citation: Venturo N, Giovanni S (2017) Improving Dermatological Signs and Symptoms with Polydatin-based Dermo-Cosmetic Products. J

Page 3 of 13

After 7,14,30 and 60 days patients were reviewed, assessing the evolution of the clinical condition.

After 30 and 60 days, both the patient and the doctor expressed the assessment of treatment efficacy (0-totally ineffective, up to 10 excellent efficacy).

The variations in the intensity of each parameter were statistically evaluated by Wilcoxon paired-sample test.

\section{Results}

Table 1 shows the descriptive analysis of the treated cases. For each item are given numerosity, mean, standard and error deviation (SD$\mathrm{SEM})$, minimum and maximum value.

\begin{tabular}{|c|c|c|c|c|c|c|}
\hline \multicolumn{2}{|l|}{ Table 1} & Sex & Age (years) & Weight(kg) & Height(cm) & Duration of illness(days) \\
\hline \multirow{6}{*}{ All } & num. & \multirow{3}{*}{$56 \mathrm{M}$} & 110 & 110 & 110 & 110 \\
\hline & mean & & 35,53 & 62,26 & 164,23 & 68,42 \\
\hline & SD & & 11,38 & 13,62 & 15,70 & 75,78 \\
\hline & SEM & \multirow{3}{*}{$54 \mathrm{~F}$} & 1,08 & 1,30 & 1,50 & 7,23 \\
\hline & $\min$ & & 16 & 32 & 125 & 7 \\
\hline & $\max$ & & 60 & 81 & 181 & 365 \\
\hline \multirow{6}{*}{ Atopic Dermatitis } & num. & \multirow{3}{*}{$34 \mathrm{M}$} & 64 & 64 & 64 & 64 \\
\hline & mean & & 29,31 & 58,88 & 159,69 & 82,39 \\
\hline & SD & & 7,90 & 14,53 & 18,23 & 80,60 \\
\hline & SEM & \multirow{3}{*}{$30 \mathrm{~F}$} & 0,99 & 1,82 & 2,28 & 10,08 \\
\hline & $\min$ & & 16 & 32 & 125 & 7 \\
\hline & $\max$ & & 48 & 77 & 180 & 365 \\
\hline \multirow{6}{*}{$\begin{array}{l}\text { Seborrheic } \\
\text { Dermatitis }\end{array}$} & num. & \multirow{3}{*}{$16 \mathrm{M}$} & 25 & 25 & 25 & 25 \\
\hline & mean & & 51,64 & 76,08 & 177,12 & 68,08 \\
\hline & SD & & 4,47 & 3,07 & 2,86 & 76,88 \\
\hline & SEM & \multirow{3}{*}{$9 \mathrm{~F}$} & 0,89 & 0,61 & 0,57 & 15,38 \\
\hline & $\min$ & & 45 & 70 & 171 & 7 \\
\hline & $\max$ & & 60 & 81 & 181 & 365 \\
\hline \multirow{6}{*}{ Eczema } & num. & \multirow{3}{*}{$6 \mathrm{M}$} & 21 & 21 & 21 & 21 \\
\hline & mean & & 35,29 & 56,14 & 162,71 & 26,24 \\
\hline & SD & & 6,04 & 4,48 & 3,18 & 35,35 \\
\hline & SEM & \multirow{3}{*}{$15 \mathrm{~F}$} & 1,32 & 0,98 & 0,69 & 7,71 \\
\hline & $\min$ & & 27 & 51 & 158 & 14 \\
\hline & $\max$ & & 46 & 64 & 168 & 180 \\
\hline
\end{tabular}

Table 1: Descriptive analysis of the treated cases.

In Tables 2 to 6 are reported the data related to the chosen symptomatology for the assessment of efficacy during treatment, such as itching, redness, skin xerosis, lichenification of the skin and eczematous lesions (measured according to the ordinary scale $0=$ absent, $1=$ present medium grade, $2=$ present high degree) and in Table 7 the sum of the symptoms.
For each item are given to the monitoring times-start and after 7,14,30 and 60 days - numerosity, mean, standard and error deviation (SD-SEM), minimum and maximum values and the $\%$ change compared to the initial value. 
Citation: Venturo N, Giovanni S (2017) Improving Dermatological Signs and Symptoms with Polydatin-based Dermo-Cosmetic Products. J Cosmo Trichol 3: 124. doi:10.4172/2471-9323.1000124

Page 4 of 13

\begin{tabular}{|c|c|c|c|c|c|c|}
\hline \multirow{2}{*}{\multicolumn{2}{|c|}{ Table 2}} & \multicolumn{5}{|c|}{ Itching } \\
\hline & & start & 7th day & 14th day & 30th day & 60th day \\
\hline \multirow{7}{*}{ All } & num. & 110 & 110 & 110 & 110 & 110 \\
\hline & mean & 1,86 & 0,44 & 0,38 & 0,24 & 0,09 \\
\hline & SD & 0,37 & 0,58 & 0,52 & 0,43 & 0,29 \\
\hline & SEM & 0,04 & 0,06 & 0,05 & 0,04 & 0,03 \\
\hline & $\min$ & 0 & 0 & 0 & 0 & 0 \\
\hline & $\max$ & 2 & 2 & 2 & 1 & 1 \\
\hline & $\%$ change & & $-77 \%$ & $-80 \%$ & $-87 \%$ & $-95 \%$ \\
\hline \multirow{7}{*}{$\begin{array}{c}\text { Atopic } \\
\text { Dermat } \\
\text { itis }\end{array}$} & num. & 64 & 64 & 64 & 64 & 64 \\
\hline & mean & 1,86 & 0,42 & 0,41 & 0,31 & 0,14 \\
\hline & SD & 0,39 & 0,56 & 0,53 & 0,47 & 0,35 \\
\hline & SEM & 0,05 & 0,07 & 0,07 & 0,06 & 0,04 \\
\hline & $\min$ & 0 & 0 & 0 & 0 & 0 \\
\hline & $\max$ & 2 & 2 & 2 & 1 & 1 \\
\hline & $\%$ change & & $-77 \%$ & $-78 \%$ & $-83 \%$ & $-92 \%$ \\
\hline \multirow{7}{*}{$\begin{array}{l}\text { Seborr } \\
\text { heic } \\
\text { Dermat } \\
\text { itis }\end{array}$} & num. & 25 & 25 & 25 & 25 & 25 \\
\hline & mean & 1,84 & 0,76 & 0,64 & 0,24 & 0,04 \\
\hline & SD & 0,37 & 0,66 & 0,57 & 0,44 & 0,20 \\
\hline & SEM & 0,07 & 0,13 & 0,11 & 0,09 & 0,04 \\
\hline & $\min$ & 1 & 0 & 0 & 0 & 0 \\
\hline & $\max$ & 2 & 2 & 2 & 1 & 1 \\
\hline & $\%$ change & & $-59 \%$ & $-65 \%$ & $-87 \%$ & $-98 \%$ \\
\hline \multirow{7}{*}{$\begin{array}{c}\text { Eczem } \\
\text { a }\end{array}$} & num. & 21 & 21 & 21 & 21 & 21 \\
\hline & mean & 1,90 & 0,10 & 0,00 & 0,00 & 0,00 \\
\hline & SD & 0,30 & 0,30 & 0,00 & 0,00 & 0,00 \\
\hline & SEM & 0,07 & 0,07 & 0,00 & 0,00 & 0,00 \\
\hline & $\min$ & 1 & 0 & 0 & 0 & 0 \\
\hline & $\max$ & 2 & 1 & 0 & 0 & 0 \\
\hline & $\%$ change & & $-95 \%$ & $-100 \%$ & $-100 \%$ & $-100 \%$ \\
\hline
\end{tabular}

Table 2: Data related to the chosen symptomatology for the assessment of efficacy during treatment for itching.

\begin{tabular}{|c|l|l|l|l|l|l|}
\hline \multirow{2}{*}{\multicolumn{2}{|c|}{ Table 3 }} & \multicolumn{5}{c|}{ Redness } \\
\cline { 3 - 8 } & start & 7 th day & 14th day & 30th day & 60 th day \\
\hline \multirow{2}{*}{ All } & num. & 107 & 107 & 107 & 107 & 107 \\
\cline { 2 - 8 } & mean & $\mathbf{1 , 9 1}$ & $\mathbf{0 , 6 3}$ & $\mathbf{0 , 4 8}$ & $\mathbf{0 , 2 7}$ & $\mathbf{0 , 1 0}$ \\
\hline
\end{tabular}


Citation: Venturo N, Giovanni S (2017) Improving Dermatological Signs and Symptoms with Polydatin-based Dermo-Cosmetic Products. J Cosmo Trichol 3: 124. doi:10.4172/2471-9323.1000124

Page 5 of 13

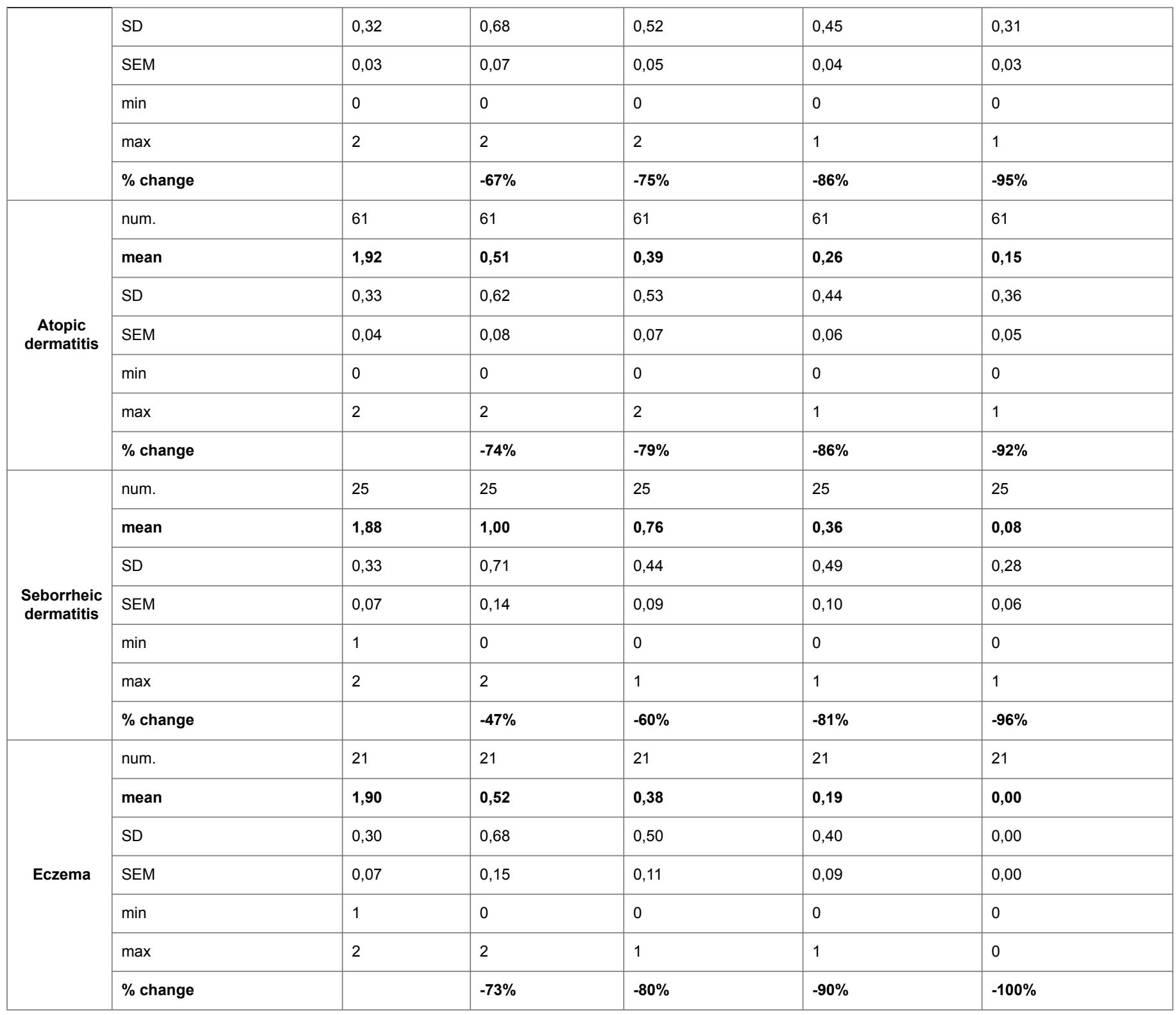

Table 3: Data related to the chosen symptomatology for the assessment of efficacy during treatment for redness.

\begin{tabular}{|c|c|c|c|c|c|c|}
\hline \multirow{2}{*}{\multicolumn{2}{|c|}{ Table 4}} & \multicolumn{5}{|c|}{ Xerosis } \\
\hline & & start & 7thday & 14th day & 30th day & 60th day \\
\hline \multirow{6}{*}{ All } & num. & 108 & 108 & 108 & 108 & 108 \\
\hline & mean & 1,66 & 0,74 & 0,39 & 0,27 & 0,16 \\
\hline & SD & 0,50 & 0,60 & 0,49 & 0,45 & 0,37 \\
\hline & SEM & 0,05 & 0,06 & 0,05 & 0,04 & 0,04 \\
\hline & $\min$ & 0 & 0 & 0 & 0 & 0 \\
\hline & $\max$ & 2 & 2 & 1 & 1 & 1 \\
\hline
\end{tabular}


Citation: Venturo N, Giovanni S (2017) Improving Dermatological Signs and Symptoms with Polydatin-based Dermo-Cosmetic Products. J Cosmo Trichol 3: 124. doi:10.4172/2471-9323.1000124

Page 6 of 13

\begin{tabular}{|c|c|c|c|c|c|c|}
\hline & $\%$ change & & $-55 \%$ & $-77 \%$ & $-84 \%$ & $-91 \%$ \\
\hline \multirow{7}{*}{$\begin{array}{c}\text { Atopic } \\
\text { dermatitis }\end{array}$} & num. & 64 & 64 & 64 & 64 & 64 \\
\hline & mean & 1,91 & 1,05 & 0,59 & 0,41 & 0,27 \\
\hline & SD & 0,34 & 0,45 & 0,50 & 0,50 & 0,45 \\
\hline & SEM & 0,04 & 0,06 & 0,06 & 0,06 & 0,06 \\
\hline & $\min$ & 0 & 0 & 0 & 0 & 0 \\
\hline & $\max$ & 2 & 2 & 1 & 1 & 1 \\
\hline & $\%$ change & & $-45 \%$ & $-69 \%$ & $-79 \%$ & $-86 \%$ \\
\hline \multirow{7}{*}{$\begin{array}{c}\text { Seborrheic } \\
\text { dermatitis }\end{array}$} & num. & 25 & 25 & 25 & 25 & 25 \\
\hline & mean & 1,44 & 0,44 & 0,16 & 0,12 & 0,00 \\
\hline & SD & 0,51 & 0,58 & 0,37 & 0,33 & 0,00 \\
\hline & SEM & 0,10 & 0,12 & 0,07 & 0,07 & 0,00 \\
\hline & $\min$ & 1 & 0 & 0 & 0 & 0 \\
\hline & $\max$ & 2 & 2 & 1 & 1 & 0 \\
\hline & $\%$ change & & $-69 \%$ & $-89 \%$ & $-92 \%$ & $-100 \%$ \\
\hline \multirow{7}{*}{ Eczema } & num. & 19 & 19 & 19 & 19 & 19 \\
\hline & mean & 1,11 & 0,11 & 0,00 & 0,00 & 0,00 \\
\hline & SD & 0,32 & 0,32 & 0,00 & 0,00 & 0,00 \\
\hline & SEM & 0,07 & 0,07 & 0,00 & 0,00 & 0,00 \\
\hline & $\min$ & 1 & 0 & 0 & 0 & 0 \\
\hline & $\max$ & 2 & 1 & 0 & 0 & 0 \\
\hline & $\%$ change & & $-90 \%$ & $-100 \%$ & $-100 \%$ & $-100 \%$ \\
\hline
\end{tabular}

Table 4: Data related to the chosen symptomatology for the assessment of efficacy during treatment for xerosis.

\begin{tabular}{|c|c|c|c|c|c|c|}
\hline & & & & & nification & \\
\hline & & & & & & \\
\hline & num. & 76 & 76 & 76 & 76 & 76 \\
\hline & mean & 1,70 & 1,07 & 0,59 & 0,45 & 0,21 \\
\hline & SD & 0,49 & 0,50 & 0,49 & 0,50 & 0,41 \\
\hline All & SEM & 0,06 & 0,06 & 0,06 & 0,06 & 0,05 \\
\hline & $\min$ & 0 & 0 & 0 & 0 & 0 \\
\hline & $\max$ & 2 & 2 & 1 & 1 & 1 \\
\hline & $\%$ change & & $-37 \%$ & $-65 \%$ & $-74 \%$ & $-88 \%$ \\
\hline & num. & 64 & 64 & 64 & 64 & 64 \\
\hline $\begin{array}{l}\text { Atopic } \\
\text { dermatitis }\end{array}$ & mean & 1,80 & 1,17 & 0,69 & 0,53 & 0,25 \\
\hline & SD & 0,44 & 0,42 & 0,47 & 0,50 & 0,44 \\
\hline
\end{tabular}


Citation: Venturo N, Giovanni S (2017) Improving Dermatological Signs and Symptoms with Polydatin-based Dermo-Cosmetic Products. J Cosmo Trichol 3: 124. doi:10.4172/2471-9323.1000124

Page 7 of 13

\begin{tabular}{|c|c|c|c|c|c|c|}
\hline & SEM & 0,06 & 0,05 & 0,06 & 0,06 & 0,05 \\
\hline & $\min$ & 0 & 0 & 0 & 0 & 0 \\
\hline & $\max$ & 2 & 2 & 1 & 1 & 1 \\
\hline & $\%$ change & & $-35 \%$ & $-62 \%$ & $-70 \%$ & $-86 \%$ \\
\hline \multirow{7}{*}{$\begin{array}{l}\text { Seborrheic } \\
\text { dermatitis }\end{array}$} & num. & 0 & 0 & 0 & 0 & 0 \\
\hline & mean & - & - & - & - & - \\
\hline & SD & - & - & - & - & - \\
\hline & SEM & - & - & - & - & - \\
\hline & $\min$ & 0 & 0 & 0 & 0 & 0 \\
\hline & $\max$ & 0 & 0 & 0 & 0 & 0 \\
\hline & $\%$ change & & - & - & - & - \\
\hline \multirow{7}{*}{ Eczema } & num. & 12 & 12 & 12 & 12 & 12 \\
\hline & mean & 1,17 & 0,50 & 0,08 & 0,00 & 0,00 \\
\hline & SD & 0,39 & 0,52 & 0,29 & 0,00 & 0,00 \\
\hline & SEM & 0,11 & 0,15 & 0,08 & 0,00 & 0,00 \\
\hline & $\min$ & 1 & 0 & 0 & 0 & 0 \\
\hline & $\max$ & 2 & 1 & 1 & 0 & 0 \\
\hline & $\%$ change & & $-57 \%$ & $-93 \%$ & $-100 \%$ & $-100 \%$ \\
\hline
\end{tabular}

Table 5: Data related to the chosen symptomatology for the assessment of efficacy during treatment for Skin lichenification.

\begin{tabular}{|c|c|c|c|c|c|c|}
\hline \multirow{2}{*}{\multicolumn{2}{|c|}{ Table 6}} & \multicolumn{5}{|c|}{ Eczematous lesions } \\
\hline & & \multirow{2}{*}{$\begin{array}{l}\text { start } \\
106\end{array}$} & \multirow{2}{*}{$\begin{array}{l}\text { 7th day } \\
106\end{array}$} & \multirow{2}{*}{$\begin{array}{l}\text { 14th day } \\
106\end{array}$} & \multirow{2}{*}{$\begin{array}{l}\text { 30th day } \\
106\end{array}$} & \multirow{2}{*}{$\begin{array}{l}\text { 60th day } \\
106\end{array}$} \\
\hline \multirow{7}{*}{ All } & num. & & & & & \\
\hline & mean & 1,84 & 1,22 & 0,60 & 0,41 & 0,27 \\
\hline & SD & 0,37 & 0,50 & 0,53 & 0,49 & 0,45 \\
\hline & SEM & 0,04 & 0,05 & 0,05 & 0,05 & 0,04 \\
\hline & $\min$ & 1 & 0 & 0 & 0 & 0 \\
\hline & $\max$ & 2 & 2 & 2 & 1 & 1 \\
\hline & $\%$ change & & $-34 \%$ & $-67 \%$ & $-78 \%$ & $-85 \%$ \\
\hline \multirow{7}{*}{$\begin{array}{c}\text { Atopic } \\
\text { Dermatitis }\end{array}$} & num. & 64 & 64 & 64 & 64 & 64 \\
\hline & mean & 1,94 & 1,34 & 0,83 & 0,59 & 0,45 \\
\hline & SD & 0,24 & 0,54 & 0,46 & 0,50 & 0,50 \\
\hline & SEM & 0,03 & 0,07 & 0,06 & 0,06 & 0,06 \\
\hline & $\min$ & 1 & 0 & 0 & 0 & 0 \\
\hline & $\max$ & 2 & 2 & 2 & 1 & 1 \\
\hline & $\%$ change & & $-31 \%$ & $-57 \%$ & $-69 \%$ & $-77 \%$ \\
\hline
\end{tabular}


Citation: Venturo N, Giovanni S (2017) Improving Dermatological Signs and Symptoms with Polydatin-based Dermo-Cosmetic Products. J Cosmo Trichol 3: 124. doi:10.4172/2471-9323.1000124

Page 8 of 13

\begin{tabular}{|c|c|c|c|c|c|c|}
\hline \multirow{7}{*}{$\begin{array}{l}\text { Seborrheic } \\
\text { Dermatitis }\end{array}$} & num. & 21 & 21 & 21 & 21 & 21 \\
\hline & mean & 1,48 & 1,05 & 0,29 & 0,19 & 0,00 \\
\hline & SD & 0,51 & 0,38 & 0,46 & 0,40 & 0,00 \\
\hline & SEM & 0,11 & 0,08 & 0,10 & 0,09 & 0,00 \\
\hline & $\min$ & 1 & 0 & 0 & 0 & 0 \\
\hline & $\max$ & 2 & 2 & 1 & 1 & 0 \\
\hline & $\%$ change & & $-29 \%$ & $-81 \%$ & $-87 \%$ & $-100 \%$ \\
\hline \multirow{7}{*}{ Eczema } & num. & 21 & 21 & 21 & 21 & 21 \\
\hline & mean & 1,90 & 1,00 & 0,24 & 0,05 & 0,00 \\
\hline & SD & 0,30 & 0,32 & 0,44 & 0,22 & 0,00 \\
\hline & SEM & 0,07 & 0,07 & 0,10 & 0,05 & 0,00 \\
\hline & $\min$ & 1 & 0 & 0 & 0 & 0 \\
\hline & $\max$ & 2 & 2 & 1 & 1 & 0 \\
\hline & $\%$ change & & $-48 \%$ & $-88 \%$ & $-98 \%$ & $-100 \%$ \\
\hline
\end{tabular}

Table 6: Data related to the chosen symptomatology for the assessment of efficacy during treatment for Eczematous lesions.

\begin{tabular}{|c|c|c|c|c|c|c|}
\hline \multirow{2}{*}{\multicolumn{2}{|c|}{ Table 7}} & \multicolumn{5}{|c|}{ Sum of Signs And Symptoms } \\
\hline & & \multirow{2}{*}{$\begin{array}{l}\text { start } \\
110\end{array}$} & \multirow{2}{*}{$\begin{array}{l}\text { 7th day } \\
110\end{array}$} & \multirow{2}{*}{$\begin{array}{l}\text { 14th day } \\
110\end{array}$} & \multirow{2}{*}{$\begin{array}{l}\text { 30th day } \\
110\end{array}$} & \multirow{2}{*}{$\begin{array}{l}\text { 60th day } \\
110\end{array}$} \\
\hline \multirow{7}{*}{ All } & num. & & & & & \\
\hline & mean & 8,29 & 3,68 & 2,22 & 1,46 & 0,75 \\
\hline & SD & 1,93 & 1,74 & 1,66 & 1,58 & 1,30 \\
\hline & SEM & 0,18 & 0,17 & 0,16 & 0,15 & 0,12 \\
\hline & $\min$ & 2 & 0 & 0 & 0 & 0 \\
\hline & $\max$ & 10 & 8 & 7 & 5 & 5 \\
\hline & $\%$ change & & $-56 \%$ & $-73 \%$ & $-82 \%$ & $-91 \%$ \\
\hline \multirow{7}{*}{$\begin{array}{c}\text { Atopic } \\
\text { dermatitis }\end{array}$} & num. & 64 & 64 & 64 & 64 & 64 \\
\hline & mean & 9,33 & 4,47 & 2,89 & 2,09 & 1,25 \\
\hline & SD & 1,48 & 1,40 & 1,66 & 1,68 & 1,50 \\
\hline & SEM & 0,19 & 0,18 & 0,21 & 0,21 & 0,19 \\
\hline & $\min$ & 2 & 2 & 0 & 0 & 0 \\
\hline & $\max$ & 10 & 8 & 7 & 5 & 5 \\
\hline & $\%$ change & & $-52 \%$ & $-69 \%$ & $-78 \%$ & $-87 \%$ \\
\hline \multirow{4}{*}{$\begin{array}{l}\text { Seborrheic } \\
\text { dermatitis }\end{array}$} & num. & 25 & 25 & 25 & 25 & 25 \\
\hline & mean & 6,40 & 3,08 & 1,80 & 0,88 & 0,12 \\
\hline & SD & 1,41 & 1,71 & 1,22 & 1,01 & 0,44 \\
\hline & SEM & 0,28 & 0,34 & 0,24 & 0,20 & 0,09 \\
\hline
\end{tabular}


Citation: Venturo N, Giovanni S (2017) Improving Dermatological Signs and Symptoms with Polydatin-based Dermo-Cosmetic Products. J

\begin{tabular}{|c|c|c|c|c|c|c|}
\hline & $\min$ & 3 & 0 & 0 & 0 & 0 \\
\hline & $\max$ & 8 & 7 & 4 & 3 & 2 \\
\hline & $\%$ change & & $-52 \%$ & $-72 \%$ & $-86 \%$ & $-98 \%$ \\
\hline \multirow{7}{*}{ Eczema } & num. & 21 & 21 & 21 & 21 & 21 \\
\hline & mean & 7,38 & 2,00 & 0,67 & 0,24 & 0,00 \\
\hline & SD & 1,50 & 1,22 & 0,48 & 0,44 & 0,00 \\
\hline & SEM & 0,33 & 0,27 & 0,11 & 0,10 & 0,00 \\
\hline & $\min$ & 3 & 0 & 0 & 0 & 0 \\
\hline & $\max$ & 9 & 4 & 1 & 1 & 0 \\
\hline & $\%$ change & & $-73 \%$ & $-91 \%$ & $-97 \%$ & $-100 \%$ \\
\hline
\end{tabular}

Table 7: The sum of signs and symptoms related to the lesions.
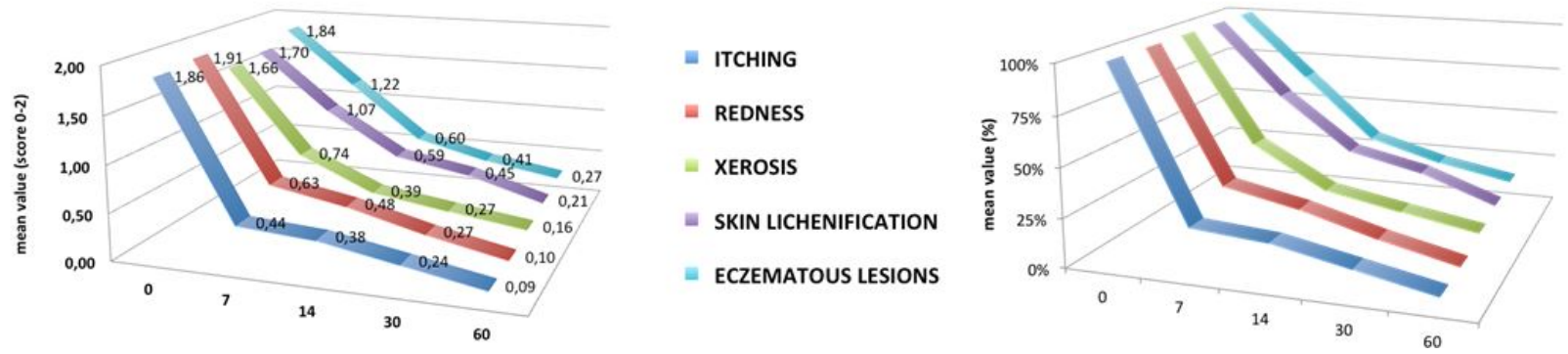

Figure 2: Global change of Symptoms in all cases processed (Mean variation of the scores of each symptom (0-2 scale) and percentage change).

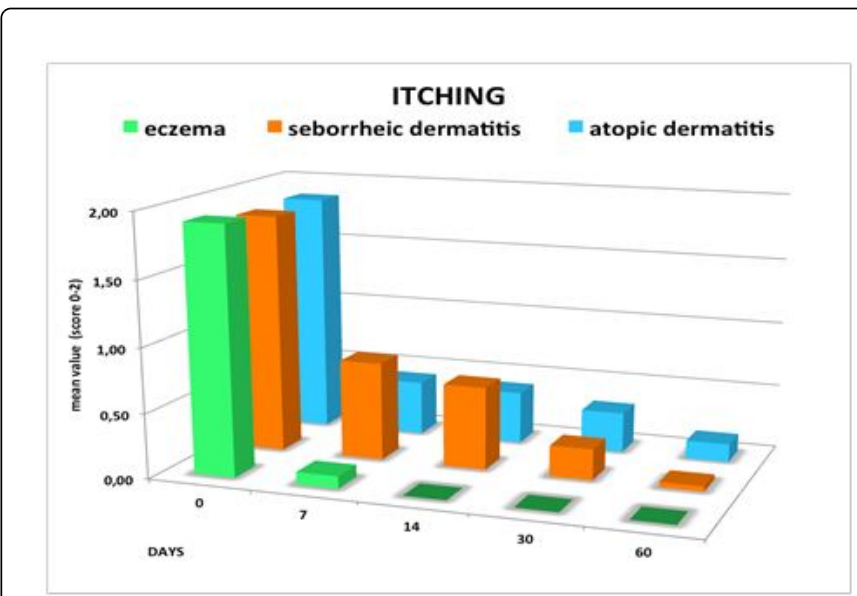

Figure 3: Itching: mean score for each control time in the groups.

The reduction in the intensity of all the parameters is statistically significant (Wilcoxon paired-sample test) and clinically relevant, whether taken individually, either when considered globally (Figure 2).

J Cosmo Trichol, an open access journal
The average change of the signs and symptoms already appears evident after the first week of treatment, consolidating and increasing within two months.

The itching (Figure 3) is rapidly reduced in subjects with atopic dermatitis (-77\%, $-83 \%$ and $-92 \%$ after 7,30 and 60 days, respectively).

In patients with seborrheic dermatitis of the face itching reduction is progressive: $-55 \%,-65 \%$ and $-98 \%$ after 7,14 and 60 days, respectively.

In patients with eczema of the face or eyelid itching completely disappears in a few days.

The redness (Figure 4) is progressively reduced $(-74 \%$ and $-79 \%$ after 7 and 14 days, respectively) up to almost completely regress in subjects with atopic dermatitis (-92\% in two months).

In patients with seborrheic dermatitis of the face there is a gradual decrease in the redness $(-47 \%$ and $-60 \%$ after 7 and 14 days, respectively, and $-96 \%$ after two months of treatment).

In patients with eczema of the face or eyelid redness it is considerably reduced in a short time $(-73 \%$ and $-80 \%$ after 7 and 14 days, respectively) until it disappears.

The xerosis (Figure 5) gradually improves in patients with atopic dermatitis (-45\%, $-69 \%$ and $-86 \%$ after 7,14 and 60 days, respectively). 
Citation: Venturo N, Giovanni S (2017) Improving Dermatological Signs and Symptoms with Polydatin-based Dermo-Cosmetic Products. J

Page 10 of 13

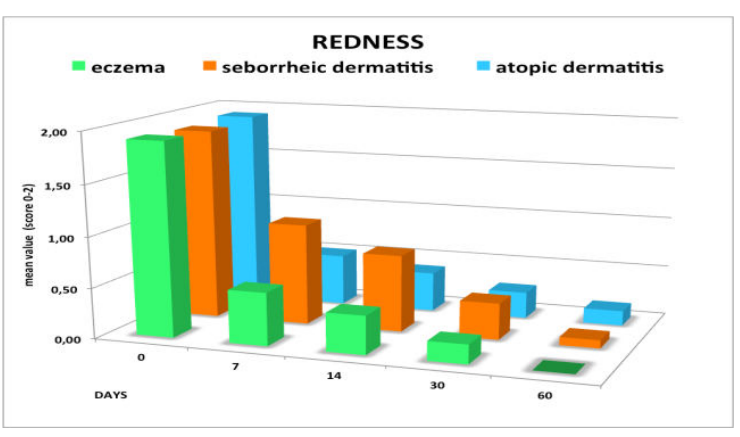

Figure 4: Redness: mean score for each control time in the groups.

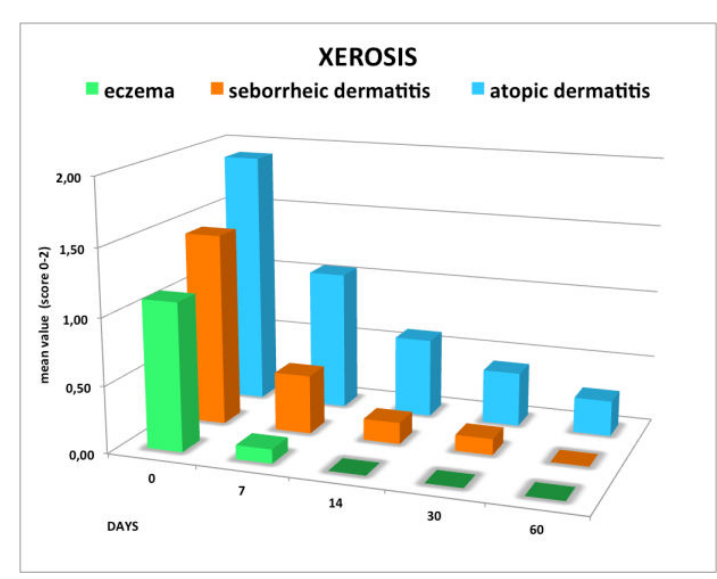

Figure 5: Xerosis: mean score for each control time in the groups.

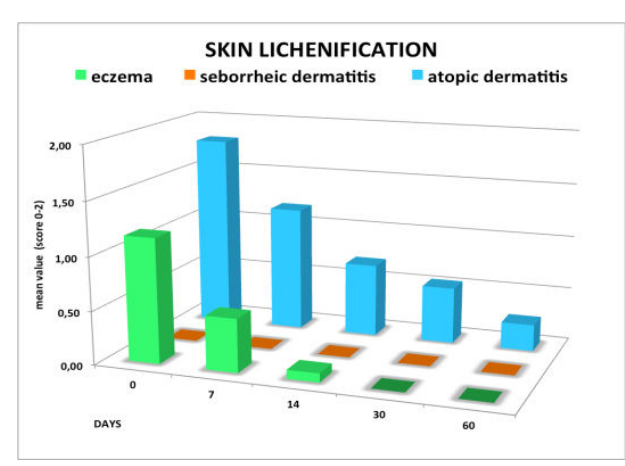

Figure 6: Skin lichenification: mean score for each control time in the groups.

In patients with seborrheic dermatitis of the face reduction the xerosis is evident and rapid (-69\% and $-89 \%$ after 7 and 14 days, respectively) until it disappears.

In patients with eczema of the face or eyelid skin xerosis disappears completely in a very short time.
The skin lichenification (Figure 6) is reduced gradually in patients with atopic dermatitis $(-35 \%,-62 \%$ and $-85 \%$ after 7,14 and 60 days, respectively).

In patients with eczema of the face or eyelid skin lichenification totally disappears in a few days.

In patients with seborrheic dermatitis of the face lichenification of the skin was not observed.

The eczematous lesions (Figure 7) in the course of atopic dermatitis rapidly declined $(-31 \%,-57 \%$ and $-77 \%$ after 7,14 and 60 days, respectively).

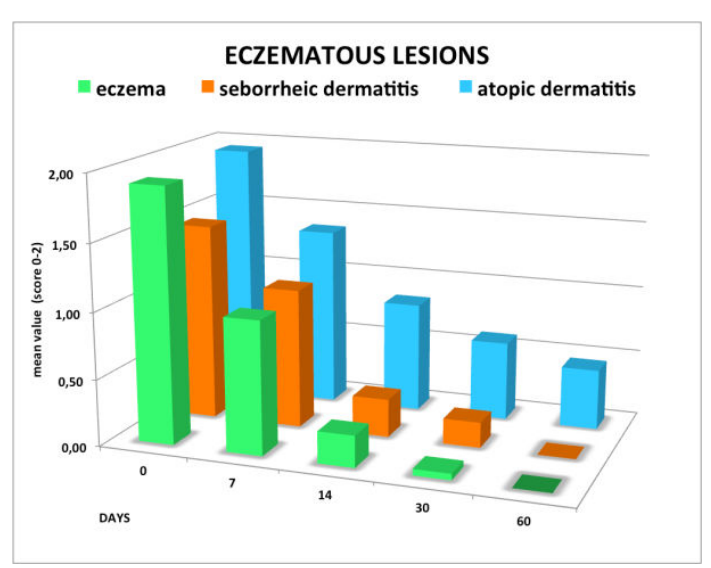

Figure 7: Eczematous Lesion: mean score for each control time in the groups.

In patients with seborrheic dermatitis of the face the reduction of atopic dermatitis was progressive (-29\% and $-81 \%$ after 7 and 14 days, respectively) until it disappears completely.

The eczematous lesions of patients with only eczema of the face or eyelid disappear completely in one to two weeks.

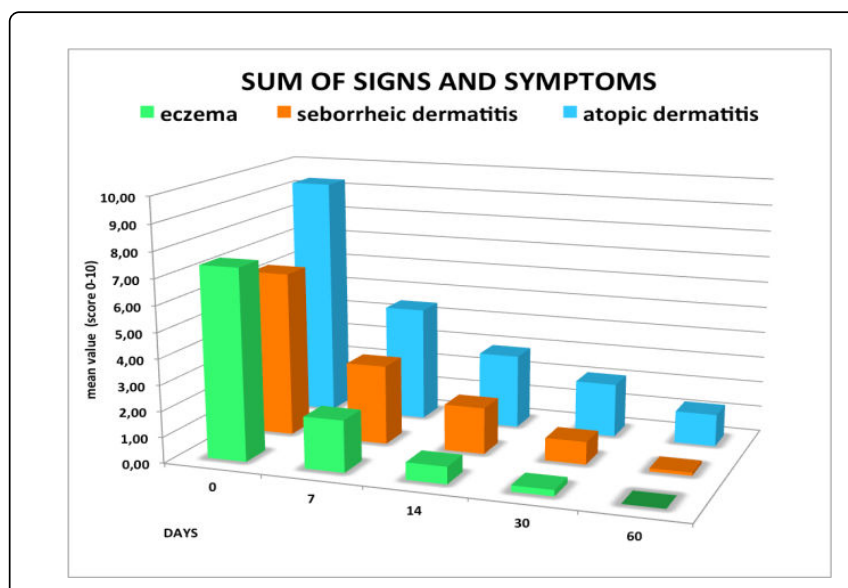

Figure 8: Sum of signs and symptoms: mean score for each control time in the groups.

The sum of signs and symptoms (Figure 8 ) in patients with atopic dermatitis gradually decreases $(-52 \%,-69 \%$ and $-87 \%$ after 7,14 and 60 
Citation: Venturo N, Giovanni S (2017) Improving Dermatological Signs and Symptoms with Polydatin-based Dermo-Cosmetic Products. J

Page 11 of 13

days, respectively). In patients with seborrheic dermatitis of the face the total reduction of signs and symptoms is progressive

(-52\% and $-72 \%$ after 7 and 14 days, respectively), up to almost completely regress (-98\% after 60 days of treatment).

The sum of the signs and symptoms in patients with eczema of the face or eyelid is reduced quickly (-29\% and $-91 \%$ after 7 and 14 days, respectively) until it disappears completely.

\section{Discussion}

The purpose of the study is to evaluate the efficacy of polydatin in improving dermatological symptoms and symptoms, describing the clinical outcome of topical treatment with polydatin in the observed cases who agreed to participate in this research.

From the data collected the intensity of the signs and symptoms showed a rapid reduction in all treated dermatitis. However, a difference in outcome is evident in the three types of dermatological diseases. In cases with atopic dermatitis, progressive improvement has been achieved, even without total disappearance of signs and symptoms after 60 days. In patients with seborrheic dermatitis, efficacy was observed with total regression of symptoms after 60 days. In cases with eczema the result was very rapid with the disappearance of the symptoms after 30 days in most cases.

An allergic cream with polydatin $1.5 \%$ and body formulation with polydatin $0.8 \%$ were used in relation to the area of the lesion to be treated in an equal way in the three groups: in atopic dermatitis 30 creams and 34 body; in seborrheic dermatitis 11 creams and 14 body; and in eczema 12 creams and 9 body.

Overall, the topical treatment with POLIDAL cream-body and POLIDAL detergent had a good efficacy in the control of all symptoms and signs that accompany the dermatoses treated, in particular atopic dermatitis, seborrheic dermatitis and eczema, as confirmed by the assessment of the physician both the patient, below (Figure 9).

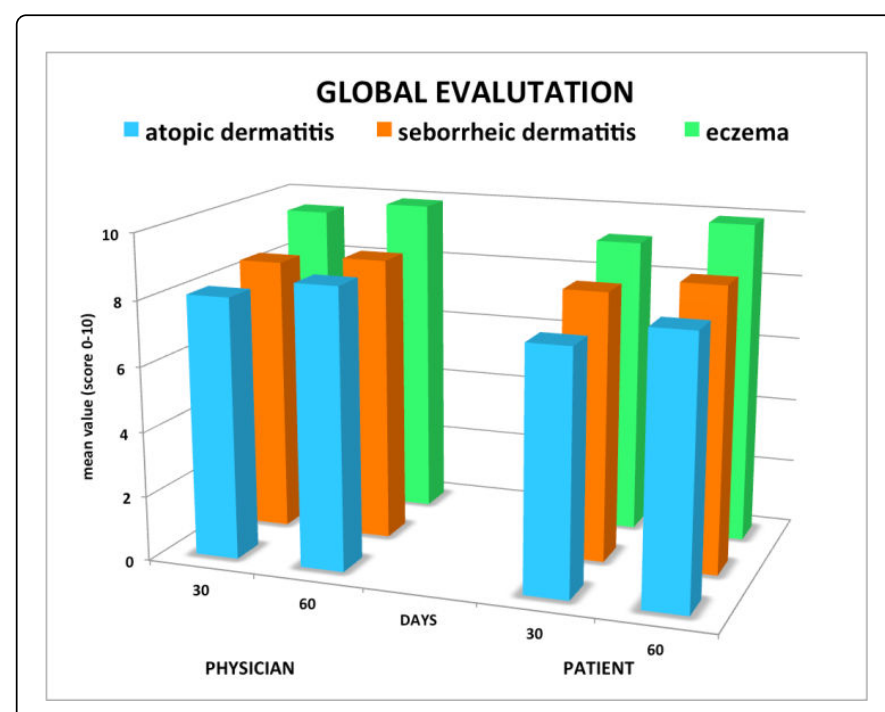

Figure 9: Physician's and patient's global evaluation: mean score after 30 and 60 days in the groups.

Table 8 shows the data of the global evaluation of the physician and the patient (according to decimal scale evaluation from 0 to 10 - from nothing to excellent).

\begin{tabular}{|c|c|c|c|c|c|}
\hline \multirow{2}{*}{\multicolumn{2}{|c|}{ Table 8}} & \multicolumn{2}{|c|}{ Physician's Global evaluation } & \multicolumn{2}{|c|}{ Patient's Global evaluation } \\
\hline & & after 30 days & after 60 days & after 30 days & after 60 days \\
\hline \multirow{6}{*}{ All } & num. & 110 & 110 & 110 & 110 \\
\hline & mean & 8,44 & 8,91 & 7,95 & 8,61 \\
\hline & SD & 1,29 & 1,30 & 1,32 & 1,47 \\
\hline & SEM & 0,12 & 0,12 & 0,13 & 0,14 \\
\hline & $\min$ & 5 & 5 & 4 & 3 \\
\hline & $\max$ & 10 & 10 & 10 & 10 \\
\hline \multirow{6}{*}{$\begin{array}{c}\text { Atopic } \\
\text { dermatitis }\end{array}$} & num. & 64 & 64 & 64 & 64 \\
\hline & mean & 8,06 & 8,64 & 7,44 & 8,14 \\
\hline & SD & 1,39 & 1,53 & 1,33 & 1,65 \\
\hline & SEM & 0,17 & 0,19 & 0,17 & 0,21 \\
\hline & $\min$ & 5 & 5 & 4 & 3 \\
\hline & $\max$ & 10 & 10 & 10 & 10 \\
\hline \multirow{2}{*}{$\begin{array}{l}\text { Seborrheic } \\
\text { dermatitis }\end{array}$} & num. & 25 & 25 & 25 & 25 \\
\hline & mean & 8,48 & 8,76 & 8,28 & 8,72 \\
\hline
\end{tabular}


Citation: Venturo N, Giovanni S (2017) Improving Dermatological Signs and Symptoms with Polydatin-based Dermo-Cosmetic Products. J Cosmo Trichol 3: 124. doi:10.4172/2471-9323.1000124

Page 12 of 13

\begin{tabular}{|c|c|c|c|c|c|}
\hline & SD & 0,82 & 0,66 & 0,94 & 0,68 \\
\hline & SEM & 0,16 & 0,13 & 0,19 & 0,14 \\
\hline & $\min$ & 7 & 8 & 6 & 7 \\
\hline & $\max$ & 10 & 10 & 10 & 10 \\
\hline \multirow{6}{*}{ Eczema } & num. & 21 & 21 & 21 & 21 \\
\hline & mean & 9,52 & 9,90 & 9,14 & 9,90 \\
\hline & SD & 0,68 & 0,30 & 0,65 & 0,30 \\
\hline & SEM & 0,15 & 0,07 & 0,14 & 0,07 \\
\hline & $\min$ & 8 & 9 & 8 & 9 \\
\hline & $\max$ & 10 & 10 & 10 & 10 \\
\hline
\end{tabular}

Table 8: Data of the global evaluation of the physician and the patient.

You may notice (Figure 10) that in most cases (from 65\% to $78 \%$ ) both the doctor and the patient, after 30 and 60 days of treatment, expressed an opinion of very good evaluation (score of 8 to 10) and in $15-35 \%$ of cases a good-enough judgment (score 5 to 7 ). Only in one case the judgment was inadequate (score from 0 to 4 ).

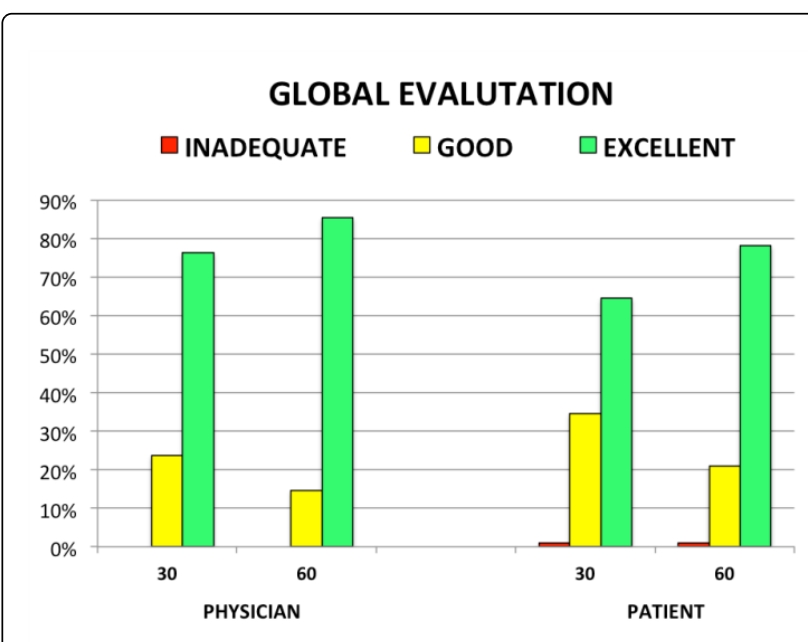

Figure 10: Physician's and patient's global evaluation: frequencies of the scores (inadequate, good, excellent) after 30 and 60 days.

\section{Conclusion}

At the end of the study, all patients had a visible clinical improvement on the polydatin-treated side, including a remarkable decrease in inflammation, itching and redness. This clinical improvement was well documented.

Our results might pave the way for a rational use of polydatin in dermocosmetics or pharmacological preparations. This molecule might thus activate the cytoprotective response and protect the skin from damage caused by pathogenic microorganisms or other environmental stressors.
The treatment was well tolerated, with no adverse effects reported on the polydatin-treated sides. All patients were satisfied with the treatment in terms of compliance, smell, texture, results, and quality of life.

Our study provides only preliminary evidence for an alternative treatment for patients affected by atopic or seborrheic dermatitis and eczema but it should be considered a valid starting point for further research into the effectiveness of polydatin at different concentrations, in innovative formulations, in larger groups of patients, and for more widespread use on the body.

\section{Acknowledgements}

Editorial support for this article was provided by Research \& Development of Ghimas (Italy).

POLIDAL is marketed by Ghimas S.p.A. (Casalecchio di Reno - BO, Italy) under exclusive license GLURES - Spin-off of Ca' Foscari University of Venice (Italy) and is the result of Italian research, with the contribution of the MIUR (RIC 1009 Decree: 16/07/2007 Legislative Decree No. 297/1999). Polydatin, natural glycoside of resveratrol, is extracted with a patented method in Europe (EP2087894A1) and Italy (0001388133 MISE).

The opinions expressed in the current article are whose of the author. The author is fully responsible for all content, editorial decision and opinions expressed in this article. The authors received no honoraria or other form of financial support related to the development of this manuscript and reported no conflicts of interest related to this study.

\section{References}

1. de Bruin Weller MS, Rockmann H, Knulst AC, Bruijnzeel-Koomen CA (2013) Evaluation of the adult patient with atopic dermatitis. Clin Exp Allergy 43: 279-291.

2. Ellis CN, Mancini AJ, Paller AS, Simpson EL, Eichenfield LF (2012) Understanding and managing atopic dermatitis in adult patients. Semin Cutan Med Surg 31: S18-22.

3. Simon D, Bieber T (2014) Systemic therapy for atopic dermatitis. Allergy 69: 46-55. 
Citation: Venturo N, Giovanni S (2017) Improving Dermatological Signs and Symptoms with Polydatin-based Dermo-Cosmetic Products. J

4. Fabris S, Momo F, Ravagnan G, Stevanato R (2008) Antioxidan properties of resveratrol and piceid on lipid peroxidation in micelles and monolamellar liposomes. Biophys Chem 135: 76-83.

5. Formulations comprising piceid and resveratrol able to prevent and inhibit lipid peroxidation - European patent EP2087894 A1-11.02.2009.

6. Boocock DJ, Faust GE, Patel KR, Schinas AM, Brown VA, et al. (2007) Phase I dose escalation pharmacokinetic study in healthy volunteers of resveratrol, a potential cancer chemopreventive agent. Cancer Epidemiol Biomarkers Prev 16: 1246-1252.

7. Du QH, Peng C, Zhang H (2013) Polydatin: a review of pharmacology and pharmacokinetics. Pharm Biol 51: 1347-1354.

8. Lv C, Zhang L, Wang Q, Liu W, Wang C, et al. (2006) Determination of piceid in rat plasma and tissues by high-performance liquid chromatographic method with UV detection. Biomed Chromatogr 20: 1260-1266.

9. Walle T, Hsieh F, DeLegge MH, Oatis JE Jr, Walle UK (2004) High absorption but very low bioavailability of oral resveratrol in humans. Drug Metab Dispos 32: 1377-1382.

10. Henry-Vitrac C, Desmouliere A, Girard D, Mérillon JM, Krisa S (2006) Transport, deglycosylation, and metabolism of trans-piceid by small intestinal epithelial cells. Eur J Nutr 45: 376-382.

11. Fuggetta M, Mattivi F (2011) The immunomodulating activities of resveratrol glucosides in humans. Recent Pat Food Nutr Agric 3: 81-90.

12. Cui XY, Kim JH, Zhao X, Chen BQ, Lee BC, et al. (2006) Antioxidative and acute anti-inflammatory effects of Campsis grandiflora flower. J Ethnopharmacol 103: 223-228.

13. Lanzilli G, Cottarelli A, Nicotera G, Guida S, Ravagnan G, et al. (2012) Anti-inflammatory effect of resveratrol and polydatin by in vitro IL-17 modulation. Inflammation 35: 240-248.

14. Yang B, Li JJ, Cao JJ, Yang CB, Liu J, et al. (2013) Polydatin attenuated food allergy via store-operated calcium channels in mast cell. World J Gastroenterol 19: 3980-3989.
15. Yuan M, Li J, Lv J, Mo X, Yang C, et al. (2012) Polydatin (PD) inhibits IgE-mediated passive cutaneous anaphylaxis in mice by stabilizing mast cells through modulating $\mathrm{Ca}^{2}+$ mobilization. Toxicol Appl Pharmacol 264: 462-469.

16. Ishikawa T, Kanda N, Hau CS, Tada Y, Watanabe S (2009) Histamine induces human beta-defensin-3 production in human keratinocytes. Dermatol Sci 56: 121-127.

17. Kanda N, Watanabe S (2004) Histamine enhances the production of granulocyte-macrophage colony-stimulating factor via protein kinase $\mathrm{Ca}$ and extracellular signal-regulated kinase in human keratinocytes. J Invest Dermatol 122: 863-872.

18. Kanda N, Watanabe S (2007) Histamine enhances the production of human beta-defensin-2 in human keratinocytes. Am J Physiol Cell Physiol 293: C1916-1923.

19. Pastore S, Lulli D, Fidanza P, Potapovich AI, Kostyuk VA, et al. (2012) Plant polyphenols regulate chemokine expression and tissue repair in human keratinocytes through interaction with cytoplasmic and nuclear components of epidermal growth factor receptor system. Antioxid Redox Signal 16: 314-328.

20. Potapovich AI, Lulli D, Fidanza P, Kostyuk VA, De Luca C, et al. (2011) Plant polyphenols differentially modulate inflammatory responses of human keratinocytes by interfering with activation of transcription factors NFkB and AhR and EGFR-ERK pathway. Toxicol Appl Pharmacol 255: 138-149.

21. Ravagnan G, De Filippis A, Cartenì M, De Maria S, Cozza V, et al. (2013) Polydatin, a natural precursor of resveratrol, induces $\beta$-defensin production and reduces inflammatory response. Inflammation 36: 26-34. 